\title{
A COMPARATIVE STUDY OF TRADITIONAL VERSUS BEST PRACTICES MANGO VALUE CHAIN
}

\author{
Mubashir Mehdi ${ }^{1, *}$, Burhan Ahmad², Asif Yaseen ${ }^{3}$, Adnan Adeel² and Nosheen Sayyed \\ ${ }^{1}$ Institute of Business Management Sciences, University of Agriculture, Faisalabad, Pakistan; ${ }^{2}$ University of \\ Agriculture, Faisalabad, Pakistan; ${ }^{3}$ ARC-Industrial Transformation Training Center, University of Queensland, \\ Australia; ${ }^{4}$ Government College for Women University, Faisalabad, Pakistan. \\ "Corresponding author's e-mail: mubashir_mehdi@hotmail.com
}

\begin{abstract}
Pakistan is the fourth largest producer of mangoes preceded by India, China and Thailand. Marketing of mangoes is mainly in private hands that are supposed to deliver quality mango in the domestic market. However, there is little evidence of developing value oriented mango chain particularly for the high end markets. Growers have attempted to deliver premium quality mangoes at the modern retail stores but due to inadequate marketing skills they were unable to maintain consistent and regular supplies. To keep continuity in transformation, there is a dire need of entrepreneurial traders who can facilitate the growers to fill the gap of connecting them with high end markets. Following the whole-of-chain approach, this study collected data from four mango farms identified in a development project, "ASLP Mango Value Chain Improvement". A wholesaler /commission agent was involved and evaluated from the Multan wholesale fruits and vegetable market. Further, an exclusive premium quality mango sale point was established in Multan Cantonment area and feedback from 100 consumers was collected who bought mango from this outlet. Our findings show the cost/ benefits analysis at the whole-of-chain level that can motivate the growers, traders, entrepreneurs and retailers to deliver premium quality mangoes to the quality conscious consumers. The main findings are quality mangoes can easiest achieve a price premium in the domestic market and growers, traders and modern food retailers have adequate benefits in delivering premium quality mangoes to the consumers.
\end{abstract}

Keywords: Mango, value chain, profitability, high end markets, best practices.

\section{INTRODUCTION}

Pakistan is the fourth largest producer of mangoes preceded by India, China and Thailand (FAO, 2014). Pakistan produces many mango varieties, which differ in harvesting time and in their physiological characteristics, especially shape, size, color, sugar level and acidity. While production is dominated by two major varieties: Chaunsa and Sindhri, other varieties such as Langra, Anwar Ratole, Dasheri Banganpalli and Neelam are cultivated to a lesser extent. Only Chaunsa and Sindhri varieties produce a significant volume of fruit to make them important from a commercial point of view. Harvesting of mango is in summer in Pakistan and harvesting time varies across varieties. Punjab and Sindh provinces are the major source of production of Mango. Total production of mango in Pakistan during 2000-2013 remained at about 1527 thousand tons whereas area under this production was about 146 thousands hectares. Punjab contributed about 62 per cent in total area under mango production in Pakistan and shared about 74 per cent of total mango production in Pakistan during 2000-2013. The province of Sindh's contribution in area and production of mango in Pakistan was about 37 per cent and 25 per cent respectively during 2000-2013 (GoP, 2014).
Marketing of mangoes is mainly in private hands and the role of the public sector is confined to creating an enabling environment that may include the provision of physical infrastructure, regulatory measures, market intelligence and market promotion. The domestic market is the major market for Pakistan mangoes, absorbing 90-95\% production (PHDEC, 2005; Ghafoor, 2010). The domestic retail markets are dominated by small retail shops, street hawkers and roadside stalls. Mango prices in these markets range from USD 0.50 per $\mathrm{kg}$ (55 Rupees (Rs.) to USD 1.50 per $\mathrm{kg}$ (160 Rupees), depending upon the type of outlet and its location (higher in more affluent metropolitan areas and less in wet markets) (ACIAR, 2007). Additionally, the prices of the mango in the domestic markets starts high at average Rs. 50 per $\mathrm{kg}$ at the start of the day and discounted up to the half of the beginning price at the end of the day. Growers' share of the consumer dollar in these markets is estimated at approximately 28 per cent (PIAM, 2007; PARC, 2009).

Well organized 'superior' retail markets are uncommon except in big cities like Karachi, Lahore, Islamabad and Faisalabad, and these retail outlets are setting trends for quality products among consumers (ACIAR, 2007). They mainly source fruit from wholesale markets and sometimes directly from commission agents (Middle men). Some additional retail markets for mangoes are multinational chains like METRO 
and national level superstores. These outlets are increasing in the major cities but are still in an introductory phase of procuring premium quality fruit from reliable sources. The problems such as market regulatory measures, inadequate knowledge about storage, grading and packing facilities, poor communication due to weak database and market intelligence and lack of participation by people (local bodies, NGOs farmers' organization and industrial association) were the major bottlenecks to establish a value chain in the domestic market (Mehdi, 2012). Consequently, an information gap emerges between producers and consumers, strengthening the position of middlemen in the chain.

To grasp the opportunities and systematic assessment of mango industry, an international project "Mango Value Chain Improvement", under the Australia-Pakistan Agriculture Sector Linkage Program (ASLP), attempted to demonstrate the benefits of ASLP best practices through a growerwholesaler- retailer value chain in 2013-14. The rationale guiding the development of this ASLP project was that the Pakistan's mango industry is needed to recognize the critical demand of quality mangoes in domestic markets, develop the technology and best practices to provide mangoes to consumers that meet their expectations and build chain partnerships delivering value to domestic consumers consistently, reliably and efficiently. This approach sought to engage key industry stakeholders from all critical segments of a chain in a rural industry development project and known as a 'whole-of-chain' focus in linking farmers to their markets (ACIAR, 2006).

ACIAR (2014) conducted a survey to estimate the potential for premium quality mango in domestic markets of Pakistan particularly in the high end retail stores. They found a very good potential in the domestic markets for premium quality mangoes. The present study is specifically designed to answer this question and estimate the profitability of producing best quality. Detailed data are collected on the costs of producing traditional (Super), VIP and ASLP best practices mangoes $(\text { Sabri })^{1}$. Super mangoes were harvested, graded and packed in wooden boxes and directly sent to the wholesale market. The traditional VIP mango production involves the same practices as Super except they are differentiated on fruit rise ranging from 350-450 gm. However, VIP mangoes were packed in wooden boxes and sent to the market in the traditional way. Whereas ASLP best practices VIP mangoes were harvested properly, de-sapped and washed with fresh water in pack house at the farm level. Sabri Plus mangoes (ASLP Brand) were only ASLP Best Practices mangoes that were properly harvested, de-sapped, washed with fresh water, ripened with Ethylene gas, packed in card board boxes and marketed through wholesale market as well as high end retail outlet (Exclusive outlet) identified in the ASLP project.

\footnotetext{
${ }^{1}$ Detail of these types of mangoes are given in the data and methods section
}

Given the existence of potential for premium quality mangoes in the domestic markets a question arises that whether it is profitable for mango growers to invest to meet the additional costs of executing best practice to produce a good quality mango? To answer this question this study is designed to calculate the cost of producing traditional (Super, VIP) and ASLP best practices mangoes. Profitability of traditional and best practices mangoes is measured through estimating the cost and revenue in the domestic market. Finally, Policy recommendation are given to promote the production of premium quality mangoes for the domestic market of Pakistan.

Higher profits are found in the ASLP best practices VIP and premium quality mangoes compared with traditional (Super) and VIP mangoes. Additional benefits of premium quality mangoes are also higher compared with the additional costs. However, return is higher if the product is sold through high end retail stores compared with the sales through commission agent in the market. This may be due to lack of interest of commission agent in selling premium quality as he was paid a fixed amount of commission. In case of sales through high end retail stores each extra rupee invested to produce premium quality mango by adopting ASLP best practice generated a return of 1.9 rupees indicating that about 90 per cent profit margin is increased.

Mango is seasonal fruit and is available during summer. Punjab and Sindh provinces are the major source of production of Mango. Sindh produces early season mango varieties starting from the month of May and ends in the month of July while mango from Punjab stays in the market during Mid June-September. Total production of mango in Pakistan during 2000-2013 remained at about 1527 thousand and showed an increase of about 5 per cent whereas area under this production was about 146 thousands hectares with same 5 per cent increase during the same period. Punjab contributed about 62 per cent in total area under mango production in Pakistan and shared about 74 per cent of total mango production in Pakistan during 2000-2013. Total production and cultivate area of mango in Punjab were 1152 thousand tons and 92 thousand hectares respectively. Both showed an increase of about 7.5 per cent during the same period. The province of Sindh's contribution in area and production of mango in Pakistan was about 37 per cent and 25 per cent respectively during 2000-2013. Total area under the production of mango in Sindh remained about 53 thousand hectares which is increased by 2.3 per cent during 2002-2013. Total production of mango in Sindh during the same period was about 365 thousand tons with the increase of about 1.3 per cent. The detailed data is presented in Table 1.

Table 2 presents the domestic consumption of the mango calculated from its production, imports and exports during 2000-2013. In general, there is an increasing trend in the 
Table 1. Area and production of mango in Pakistan.

\begin{tabular}{llllll}
\hline & Punjab & Sindh & KPK & Baluchistan & Pakistan \\
\hline Harvest season & June-September & May-July & June-July & July & May-September \\
Area under Production & Increase (7.9\%) & Slight Increase (2.3\%) & Increase (5.3\%) & Decrease (6.7) & Increase (5.0\%) \\
('000ha) Average 2000-13 & 92.0 & 52.4 & 0.3 & 1.4 & 146.1 \\
Production volume ('000t) & Increase (7.4\%) & Slight Increase (1.3\%) & Increase (2.8) & Decrease (9\%) & Increase (5.1\%) \\
average 2000-13 & 1152.2 & 365.3 & 3.2 & 6.9 & 1527.3 \\
Average yield (t/ha) & Decrease (0.5) & Decrease (1.0) & Decrease 0.5) & Decrease (5.3) & Decrease (0.2) \\
2000-13 & 12.6 & 7.0 & 10.4 & 5.2 & 10.4 \\
Area \% 2000-13 & 61.6 & 37.1 & 0.2 & 1.1 & 100 \\
Production \% 2000-13 & 74.1 & 25.2 & 0.2 & 0.5 & 100 \\
\hline
\end{tabular}

Source: (GoP, 2014) + Authors calculations

Table 2. Domestic consumption and export of mango from Pakistan (tons) 2000-2013.

\begin{tabular}{|c|c|c|c|c|c|c|c|}
\hline Year & Production & Imports & Exports & $\begin{array}{c}25 \% \text { Post- } \\
\text { harvest losses }\end{array}$ & Consumption & $\begin{array}{l}\text { Export \% of } \\
\text { Prod }\end{array}$ & $\begin{array}{l}\text { Cons \% } \\
\text { of Prod }\end{array}$ \\
\hline 2000 & 937705.0 & 0 & 48453.0 & 234426.3 & 69433.0 & 5.2 & 69.8 \\
\hline 2001 & 989790.0 & 0 & 52465.0 & 247447.5 & 62146.5 & 5.3 & 69.7 \\
\hline 2002 & 1037140.0 & 0 & 47561.0 & 259285.0 & 65391.5 & 4.6 & 70.4 \\
\hline 2003 & 1034580.0 & 0 & 60441.0 & 258645.0 & 90359.8 & 5.8 & 69.2 \\
\hline 2004 & 1055990.0 & 0 & 82059.0 & 263997.5 & 73251.3 & 7.8 & 67.2 \\
\hline 2005 & 1673950.0 & 0 & 48855.0 & 418487.5 & 92904.0 & 2.9 & 72.1 \\
\hline 2006 & 1753910.0 & 0 & 105598.0 & 438477.5 & 91484.0 & 6.0 & 69.0 \\
\hline 2007 & 1719180.0 & 0 & 62057.0 & 429795.0 & 109717.8 & 3.6 & 71.4 \\
\hline 2008 & 1753686.0 & 0 & 69324.0 & 438421.5 & 156091.3 & 4.0 & 71.0 \\
\hline 2009 & 1727932.0 & 0 & 73575.0 & 431983.0 & 133430.0 & 4.3 & 70.7 \\
\hline 2010 & 1845528.0 & 0 & 85923.0 & 461382.0 & 107095.8 & 4.7 & 70.3 \\
\hline 2011 & 1888449.0 & 1 & 105130.0 & 472112.3 & 89591.0 & 5.6 & 69.4 \\
\hline Average & 1451486.7 & 0.1 & 70120.1 & 362871.7 & 1018495.0 & 4.8 & 70.2 \\
\hline
\end{tabular}

Source: (UN FAO, 2015) + Authors calculations

Note: Consumption $=$ Production + Imports - Exports - Post-harvest losses (all values are in tons)

production, exports and domestic consumption while imports remained zero during the same period. Majority of the mango production is consumed domestically which is about 70 per cent while 20-25 per cent are the post-harvest losses and about 5 per cent is being exported. Pakistan produced about 5 per cent of total world production of mango and shared about 7 per cent of the total world export of mangoes during 20002013. Recently, a considerable increase in the mango exports is witnessed because of adopting best pre and post-harvest practices to produce premium quality mangoes. Such best practices are essential for exporting as international buyers are conscious about quality and food security. Moreover, exporters have to abide by the rules and regulations regarding imports and exports. Domestic markets lack such rules and regulation regarding quality and food safety, however, this is also the right of domestic consumers to buy quality and safe food.

Objectively, quality is the aptitude of a product to satisfy the needs of its end users that must be maintained along the chain such as farm to retailers (Batt, 2005). The concept of "premium quality" mango was introduced in Pakistan mango industry with the inception of Australia-Pakistan Agriculture Sector Linkage Program (ASLP) in 2006. Pakistani consumer's perceptions toward best quality mangoes were documented in domestic market research activity under the mango value chain project. The research indicated that consumers are willing to pay $20-25$ per cent premium price for clean, blemish free, fully matured and uniform size of mango (ACIAR, 2007). It was witnessed that market does exists for such quality fruits at the high end market in the big metropolitan cities.

The common reaction among the growers regarding premium quality mango market is continuing to be successful to produce the desired mangoes for the market (Mehdi et al., 2014). However, the mango growers have not been able to find a positive response from the wholesalers and retailers over the time. This is not surprising as the middle men being closer to retailers understand the benefits of improved quality 
but their attitude is more towards volume focused than quality.

A contributing factor to the attitude of middlemen were the leading players in the existing wholesale markets and had developed skills and practices that were very effective in dealing with large quantities of variable quality fruit in a very short time frame. Hence their financial incentive was tied to volume not quality. Their reluctance to pay growers a premium for fruit prepared under the ASLP 'best practice' guidelines was influence by the lack of incentive for them to find customers/retailers who could absorb volume and were willing to pay for quality.

As a result, the mango industry appeared weak to establish a reputation as being a source of reliable, good quality, value for money fresh mangoes at superior quality fruit outlets or supermarket chains in metropolitan areas. There appears a significant scope to improve the performance and value of the Pakistani Mango in the local markets because modern food retailing is diffusing rapidly. Keeping this in view, the present study is designed to investigate the potentials and dynamics of mango industry that can guide to establish a premium quality value chain in the domestic market. Based on the analysis of primary and secondary sources of information, an empirical model of domestic mango value chain system is suggested and appropriate policy interventions by the respective department is recommended.

\section{MATERIALS AND METHODS}

Sampling method and sample size: The analysis is executed on data collected from four mango farms identified in a development project, ASLP mango value chain project, in which the workers and the supervisors of the farm got detailed training for producing premium quality mango. A wholesaler /commission agent was involved and evaluated from the Multan wholesale fruits and vegetable market. An exclusive mango outlet was established in Multan Cantonment area and feedback from 100 consumers was collected who bought mango from the exclusive outlet. About 20 retailers were randomly selected from Multan through maximum variation sampling method to collect data of traditional mangoes at retail level.

Profitability analysis: The main objective of every business is the profit maximization. This study is also designed to do a profitability analysis of production and sales of premium quality mango and traditional mango. Specifically, we are looking for whether the adoption of best practices and resulting additional investment is profitable for the producers, in particular, and for the whole value chain, in general. Theories of cost and revenue suggest the following formula to calculate the profit (Mankiw, 2014; McConnell and Brue, 2005). '

$$
\pi=T R-T C
$$

Where $\pi$ denotes the profit while TR and TC are the total revenue and total cost which are calculated as following:

$$
T R=Q \times P
$$

Where, $\mathrm{Q}$ shows the total sales of the product (mango) while $\mathrm{P}$ is the price. Total cost is comprised of fixed and variable costs described as follows:

$$
T C=T F C+T V C
$$

Where, TFC and TVC denote total fixed cost and total variable cost respectively. We are not including the fixed cost in the calculations of profit in the present study as our focus is to analyze the additional costs and benefits incurred in the production and sales of premium quality mango compared with the traditional mango. As described above that main differences are in the pre-harvest and post-harvest practices which are variable in nature. Secondly, fixed cost is the cost of the establishing a mango orchard which includes land, time and plantation etc. which are covered overtime and remain constant both for premium and traditionally produced mangoes.

Total variable cost in the present study is divided into four main parts which are pre- and post-harvest costs, logistics cost and opportunity costs of the grower. These are described as follows:

$$
\mathrm{TVC}=\mathrm{PRHC}+\mathrm{POHC}+\mathrm{LOGC}+\mathrm{WCOC}
$$

Where PRHC stands for pre-harvest costs while POHC symbolize post-harvest costs, LOGC denotes the logistics costs incurred by the farmers and WCOC is the working capital defined as the opportunity cost of the grower. The detailed procedure to calculate pre- and post-harvest costs, logistics costs and cost of working capital (opportunity cost) is given below.

$\mathrm{PRHC}=\mathrm{PLC}+\mathrm{FNC}+\mathrm{PSC}+\mathrm{LBC}+\mathrm{PRC}+\mathrm{CLC}$

Where PLC denotes ploughing cost, FNC and PSC represents Fungicide and Pesticide Cost, LBC shows labor costs whereas PRC and CLC indicate pruning/practices cost and cost for clearance of Malformation respectively. These costs are measured in terms of work hours performed by the respective labors to ensure minimum quality level e.g. super quality, at the pre-harvest stage.

Post-harvest costs are calculated at two levels depending on the practices and quality of mangoes. These levels represent the costs at Farm level and Pack House level and are described below.

$$
\mathrm{POHC}=\mathrm{FMC}+\mathrm{PHC}
$$

Where FMC shows the costs of operations/post-harvest practices performed at the farm while PHC reflects the costs incurred on the operations at Pack House. Detailed components of these practices are illustrated below.

$$
\mathrm{FMC}=\mathrm{HPC}+\mathrm{FPC}+\mathrm{GPC}+\mathrm{PMC} \quad \text { (7) }
$$

Where HPC indicates the cost of harvesting/picking, FPC shows the costs incurred to carry the mango from Farm to Pack house while GPC and PMC denote the costs of grading/packing and wooden boxed used as packing material for the packing of traditional mangoes to sale in the domestic markets. The costs incurred in the performance of post- 
harvest activities in pack house are described below.

$\mathrm{PHC}=\mathrm{DSC}+\mathrm{WDC}+\mathrm{RPC}+\mathrm{GPC}+\mathrm{PMC}$

Where DSC reflects the cost de-sapping, WDC shows the costs incurred from washing to drying mango in pack house, $\mathrm{RPC}$ reflects the ripening cost using ethylene gas in the ethylene chambers while GPC denote the costs of grading/packing. The packing is done into the cardboard boxes and PMC is the cost of cardboard boxes as packing material for the packing of premium quality mangoes to sale in the domestic as well as in high end markets.

The logistics costs to transport the mangoes from farm to market/high end retail market are illustrated as follows:

$$
\mathrm{LOGC}=\mathrm{LDC}+\mathrm{TRC}+\mathrm{UDC}+\mathrm{MFC} \text { (9) }
$$

Where LDC is the cost of loading mangoes into the transport vehicle at the farm whereas UDC is the cost of unloading mangoes from the vehicle in the market or high end retail store, TRC exhibits the transport cost of the vehicle to move the mangoes from farm to market and MFC is the marketing/commission fee charged by the commission agent. All these costs are measured for four types of mangoes, SUPER, VIP, ASLP through wholesale markets and ASLP mangoes through exclusive outlet. Total profit/margin using equation $1(\pi=T R-T C)$ is calculated for each type of mango to compare the profitability of the farmer for each chain. Moreover, one of the main objective is to calculate the value addition in ASLP best practices mango which is calculated as follows:

$$
\mathrm{VAD}=\mathrm{VPQM}-\mathrm{VSUP} \text { or VVIP }
$$

Where VAD stands for value addition due to the adoption of ASLP best practices while VPQM represents the value of premium quality mangoes and VSUP and VVIP shows the value of the Super and the value of the VIP mangoes, respectively.

As ASLP best practices premium quality mangoes require additional practices and costs compared with the traditional mangoes, the main objective is to calculate these additional costs and resulting benefits in order to measure and evaluate the profitability of the additional investment on these costs. Hence a benefit cost ration (BCR) of the additional benefits due to additional costs is calculated to measure the profitability of the additional investment to produce and sale premium quality mangoes. BCR is calculated as follows:

$$
\mathrm{BCR}=(\mathrm{VPQM}-\mathrm{VSUP} \text { or VVIP }) /(\mathrm{PMQC}-\mathrm{SUPC}
$$$$
\text { or VIPC) }
$$

Where PMQC is the total cost incurred to produce and sale premium quality mangoes through adopting ASLP best practices while SUPC is the total cost of producing and selling the traditional mango by the mango growers. A greater than 1 value of BCR reflects the higher additional benefits/profits compared with the additional costs and opposite would be the case for a less than 1 value of BCR. A value of BCR equal to 1 represents a neutral situation of no profit no loss.

In the similar way BCR are also calculated for wholesalers/ commission agents and retailers which would be helpful in calculating the total profitability of each Chain. Further the analysis would be enhanced to characterize and map the traditional and ASLP best practice mango value.

\section{RESULTS AND DISCUSSION}

Characterization and mapping of mango value chains: The traditional mango marketing system in Pakistan is dominated by contractors and commission agents. The majority of contractors obtain loans from commission agents to pay the initial installment to the mango growers and to pay an advance for labor and packing material. Under this system, once a loan has been extended, the contractor is obliged to supply mangoes to that commission agent. The commission agents have the power to control the mango supply through contractors. In the early season, they encourage contractors to bring their mangoes to the market as they can earn higher prices. Whereas in mid-season they encourage the contractors to delay the harvest as they can get a better price in late season. As a result, a huge supply glut is a norm in wholesale markets during the mid-season. Under these conditions, commission agents do not own the title of the fruit and charge the commission ( 7 per cent on sales volumes) through open auction. These attempts to manage supply have an impact not only on price but also on fruit quality, in terms fruit size, maturity and wastage.

Ninety two percent of mangoes are sold in wholesale markets through an open auction conducted by the individual commission agents where the buyers bid for boxes of mangoes offered for sale. The opening price for the auction is set by the commission agents on the basis of the grade (VIP or Super) indicated on the box or the general appearance of first layer of fruit in the box. If the offer is too low the lot can be withdrawn but this option is limited by the short shelf life of the fruit and the lack of storage facilities. This traditional auction based selling system raises many issues in terms of bargaining, contract enforcement and information access that limited the growers' margin up to 38 per cent and reduce their motivation to produce premium quality mangoes.

Consequently, there is no evidence of a value-oriented approach to supply chain management and due to the systemic impediments to production, postharvest and marketing (domestic and export), the overall performance of the mango industry in Pakistan does not match the potential of the industry. An attempt was taken by the ASLP marketing team to develop premium quality mango chain under the guideline of ASLP best practice mangoes. The studies showed that growers can earn 92 per cent more profit while selling through the exclusive outlet. Similarly, the retailer can increase their profit by 200 per cent while procuring ASLP best practice mangoes directly from exclusive outlet instead of from wholesale market. The characterization of mango value chain, both for traditional and ASLP best practice mangoes 


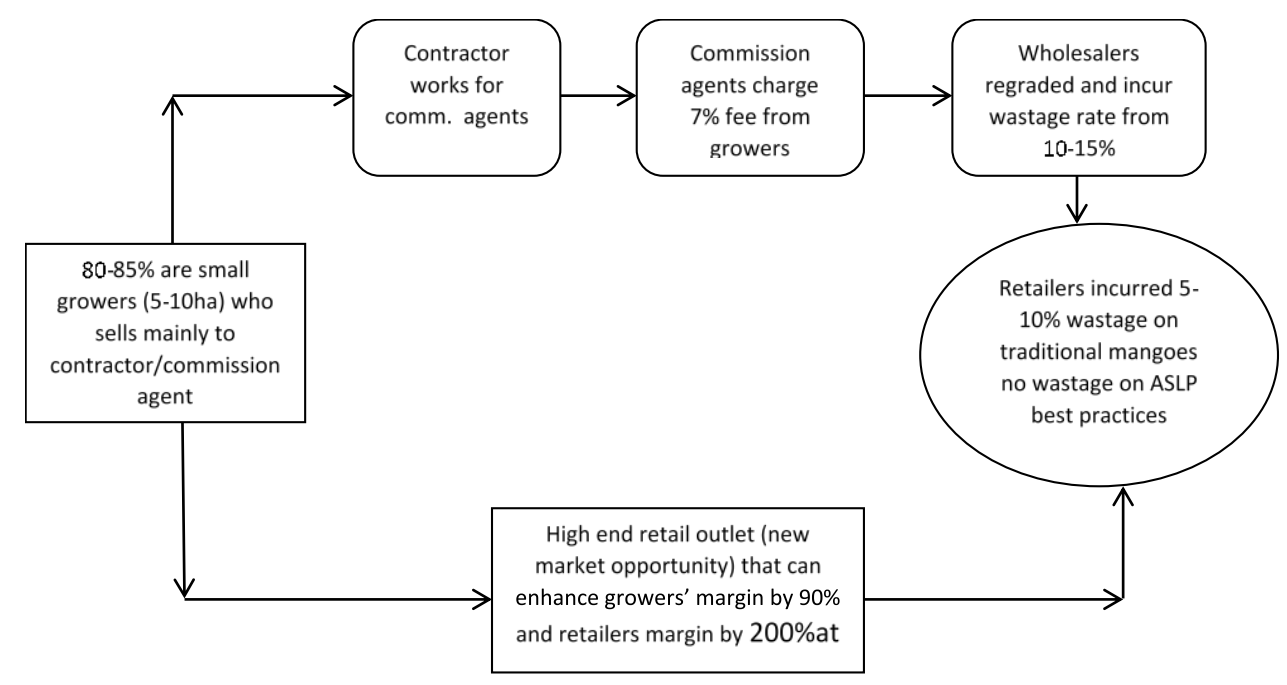

Figure 1. Mapping of traditional versus improved mango value chains.

are depicted in the Figure $1 .{ }^{2}$ Profitability of premium quality mango production: As present study is specifically seeking the profitability of production and sales of premium quality mangoes for the domestic markets of Pakistan, detailed data on pre- and post-harvest costs was collected and profit margins were calculated for all four categories of mangoes. The results are presented in Table 3. Results reveal that premium quality mango is more profitable compared with Super and VIP. The sales of premium quality through high end retail outlets (exclusive outlet) earned highest profit of about $45 \mathrm{Rs}$ per $\mathrm{Kg}$ which is $22 \mathrm{Rs}$ per $\mathrm{Kg}$ higher than the profit of selling traditional/Super quality mango through commission agent in the wholesale market. It was found that profit of ASLP best practices (premium quality) mango sold through the commission agent in the wholesale markets was higher than that of Super mangoes but less than that of VIP mangoes. This suggest that high end markets/superior outlets are the most profitable selling point premium quality mangoes produced through ASLP best practices. This nature of the profitability can be explained in two ways. Firstly, commission agents in the wholesale markets get a fixed commission and are not interested in its marketing and selling and getting a good price. This can be viewed from the results presented in Table 4, where commission agents don't have any margin/profit in selling premium quality mangoes. Secondly, high end retail outlets possess potential customers for premium quality mangoes who are quality conscious and can pay good price for the premium quality.

Profits of the growers are calculated using equation $1(\pi=T R$ $-T C$ ) by deducting total farm costs which are the sum of preand post-harvest costs, logistics costs and opportunity cost (working capital) of the work of the growers from the revenue. The costs and revenues are measured in rupees per kilogram hence the price per $\mathrm{Kg}$ is the revenue per $\mathrm{kg}$ and resulting profit is also presented in $\mathrm{Rs}$ per $\mathrm{Kg}$. Total preharvest cost remained the same for all four categories of the

Table 3. Growers profit/margin (Rs/Kg).

\begin{tabular}{lcccc}
\hline Description & $\begin{array}{c}\text { Super mangoes } \\
\text { through wholesale } \\
\text { market }\end{array}$ & $\begin{array}{c}\text { VIP mangoes } \\
\text { through wholesale } \\
\text { market }\end{array}$ & $\begin{array}{c}\text { ASLP mangoes } \\
\text { through wholesale } \\
\text { market }\end{array}$ & $\begin{array}{c}\text { ASLP mangoes } \\
\text { through exclusive } \\
\text { outlet }\end{array}$ \\
\hline Pre-Harvest Costs & 4.38 & 4.38 & 4.38 & 4.38 \\
Post-Harvest Costs & 7.65 & 17.03 & 29.62 & 29.62 \\
Logistics Costs & 6.22 & 7.55 & 5 & 7 \\
Working Capital (Opportunity costs) & 3 & 3 & 3 & 3 \\
Total Costs & 21.25 & 31.95 & 42.00 & 44.00 \\
Farm Gate Price & 44.73 & 64.35 & 73.33 & 88.88 \\
Grower's Margin/Profit & 23.49 & 32.45 & 31.33 & 44.88 \\
Additional Profit & & 8.96 & 7.84 & 21.39 \\
\hline
\end{tabular}

Authors' calculations

${ }^{2}$ Detailed calculation of various costs of the players of the value chain are given in the Appendices 7-10. 
Table 4. Wholesalers profit/margin ( $\mathrm{Rs} / \mathrm{Kg})$.

\begin{tabular}{lcccc}
\hline Description & $\begin{array}{c}\text { Super mangoes } \\
\text { through } \\
\text { wholesale market }\end{array}$ & $\begin{array}{c}\text { VIP mangoes } \\
\text { through } \\
\text { wholesale market }\end{array}$ & $\begin{array}{c}\text { ASLP mangoes } \\
\text { through wholesale } \\
\text { market }\end{array}$ & $\begin{array}{c}\text { ASLP mangoes } \\
\text { through exclusive } \\
\text { outlet }\end{array}$ \\
\hline Wastage & $1.38(3 \%)$ & $0.65(1 \%)$ & -- & -- \\
Wholesaler Costs & 3 & 3 & 3 & -- \\
Commission Fee & $3.22(7 \%)$ & $4.55(7 \%)$ & 3 & -- \\
Wholesaler's Margin & 0.22 & 1.55 & 0 & -- \\
Wholesaler's Price & 46.11 & 65 & 73.33 & -- \\
\hline
\end{tabular}

Authors' calculations

Table 5. Retailers profit/margin (Rs/Kg).

\begin{tabular}{lcccc}
\hline Description & $\begin{array}{c}\text { Super mangoes } \\
\text { through } \\
\text { wholesale market }\end{array}$ & $\begin{array}{c}\text { VIP mangoes } \\
\text { through } \\
\text { wholesale market }\end{array}$ & $\begin{array}{c}\text { ASLP mangoes } \\
\text { through wholesale } \\
\text { market }\end{array}$ & $\begin{array}{c}\text { ASLP mangoes } \\
\text { through exclusive } \\
\text { outlet }\end{array}$ \\
\hline Wholesaler's Price & 46.11 & 65.00 & 73.33 & -- \\
Retailer's Costs & 54.77 & 73.66 & 81.66 & 97.21 \\
Retailer's Prices & 59.44 & 81.11 & 100.0 & 120.0 \\
Retailer's Margin & 4.67 & 7.45 & 18.34 & 22.79 \\
\hline
\end{tabular}

mango under study which is equal to $4.38 \mathrm{Rs} / \mathrm{Kg}$, while total post-harvest varied across these four categories as the post/harvest practices were different. The detailed calculations of post-harvest costs are presented later in the text.

Total post-harvest costs of the traditional and VIP mangoes after adding logistics and opportunity costs of the growers were about $21 \mathrm{Rs} / \mathrm{Kg}$ and $32 \mathrm{Rs} / \mathrm{Kg}$ respectively while these cots for premium quality mangoes sold through wholesale market and high end retail outlet were 42 and $44 \mathrm{Rs} / \mathrm{Kg}$ respectively. The pries obtained are also different across four categories of the mangoes. The highest farm gate prices were obtained for the premium quality mangoes sold through high end retail outlet which is about $90 \mathrm{Rs} / \mathrm{Kg}$ while lowest prices were obtained for the super mangoes which were about 45 $\mathrm{Rs} / \mathrm{Kg}$. Similarly, premium quality mangoes sold through high end retail markets earned maximum profit of about 45 $\mathrm{Rs} / \mathrm{Kg}$ for the growers while lowest profit was obtained by the growers from Super mangoes which is about $23.5 \mathrm{Rs} / \mathrm{Kg}$. However, premium quality mangoes did not get higher profits in the wholesale market as they got in the high end retail outlets. Premium quality mangoes earned a profit of 31.3 $\mathrm{Rs} / \mathrm{Kg}$ in the wholesale market while VIP mangoes earned a profit of $32.4 \mathrm{Rs} / \mathrm{Kg}$ to the growers which is higher than the premium quality mangoes. However, premium quality mangoes profit was higher than the traditional mangoes. Hence, it can be stated that VIP and ASLP best practices mangoes incurred additional costs compared with the traditional mangoes and resulting profits of VIP and Premium quality mangoes are also higher than that of Super mangoes. Premium quality mangoes earned highest profit if sold through exclusive outlets while in the wholesale market VIP mangoes earned highest profits.
Table 4 represents the costs and margins of wholesalers/ commission agents selling in the wholesale markets. Commission agents charge a commission fee to sell the product or bringing together the producers and buyers. He charges about 3.5 per cent each from grower and buyer (wholesalers/retailer) totaling to 7 per cent and incurred about $3 \mathrm{Rs} / \mathrm{Kg}$ as a cost of handling in the wholesale market. He earned a commission of about $3.22 \mathrm{Rs} / \mathrm{Kg}$ in case of Super mangoes resulting in a net margin/profit of about $0.22 \mathrm{Rs} . / \mathrm{Kg}$. In case of VIP mangoes, he earned a profit of $1.55 \mathrm{Rs} / \mathrm{Kg}$ because of the size of the mangoes which is around 350-400 gm. In case of ASLP best practice premium quality mangoes, commission agent did not get any profit/margin as the commission was fixed to $3 \mathrm{Rs} / \mathrm{Kg}$ and he incurred a cost of 3 $\mathrm{Rs} / \mathrm{Kg}$. The fixed amount of commission is because of the mango quality which ensured in the form of uniform grading free from chemical carbide ripening and cardboard packaging. These quality attributes ensure zero wastage rate therefore reduce cost. This is the reason for lack of interest of commission agent to sell premium quality mangoes as they had developed skills and practices that were very effective in dealing with large quantities of variable quality fruit in a very short time frame which strengthened their position to claim cost in form of wastage from the growers. Hence their financial incentive was tied to volume not quality.

Above description shows the role of commission agent in principle, however, this is a part of total role of commission agent in the supply chain. In fact, he is the financer of both grower and retailer. He provides finances to grower particularly to small growers to meet their costs and the grower is bound to provide the produce to him to sell. In this way commission agent ensures his supply. He deducts his finances and commission from the sale of the produce and 
gives back rest of the money to grower. Similarly, retailers purchase the product from commission agent on credit and pay after selling the produce and again buy the new produce. As this is a regular purchase by the retailers almost daily in the season, retailers do not pay daily rather with some intervals/days. This financing role of the commission agent shows that he possesses a central position in the supply chain and to some extent has a control over the supply chain. Apparently, there is no interest rate charged by the commission agent for his financing, however, a hidden interest rate may be present as they mainly kept the record of selling of fruit for growers. A lack of trust always prevailed between the grower and commission agents on actual sale price and the price received by the grower.

Table 5 shows the profit/margins of the retailers across the sales of four categories of the mangoes. Higher profits were earned by the retailers of premium quality mangoes while highest profit of $23 \mathrm{Rs} / \mathrm{Kg}$ were earned by the retailers of high end retail outlets. Profits of other retailers of premium quality through wholesale markets, VIP and Super are about 18, 8, and $5 \mathrm{Rs} / \mathrm{Kg}$ respectively. Hence, it can be stated that premium quality mangoes particularly through high end retail outlets generated maximum profits for each actor in the supply chain and its production for the domestic markets should be encouraged and commercialized to earn maximum of the profits.

Table 6 presents the benefit to cost ratios incurred because of the adoption of ASLP best practices to produce premium quality mangoes using equation 11. As premium quality mangoes were marketed employing two channels, one directly to High end exclusive retail markets Table 6) while the other channel included commission agents in the wholesale markets. Super and VIP mangoes marketed through commission agents in the wholesale markets. These

Table 6. Growers additional benefit to cost ratio.

\begin{tabular}{lll}
\hline & Mango Growers & Retailers/Exclusive outlet \\
\hline SUP v/s H - Premium & $44.15 / 22.545=1.96$ & $60.56 / 42.44=1.42$ \\
VIP v/s H - Premium & $24.53 / 12.05=2.04$ & $38.89 / 23.55=1.65$ \\
M - Premium v/s H - Premium & $13.55 / 2=6.77$ & $20 / 15.55=1.29$ \\
SUP v/s M - Premium & $28.6 / 20.75=1.38$ & $40.56 / 26.89=1.51$ \\
VIP v/s M - Premium & $8.98 / 10.05=0.89$ & $18.89 / 8=2.37$ \\
SUP v/s VIP & $19.62 / 10.7=1.83$ & $21.67 / 18.89=1.15$ \\
\hline
\end{tabular}

Appendix 7. Pre-harvest costs (Rs/Kg).

\begin{tabular}{llcccc}
\hline Description & & $\begin{array}{c}\text { Super mangoes } \\
\text { through } \\
\text { wholesale market }\end{array}$ & $\begin{array}{c}\text { VIP mangoes } \\
\text { through } \\
\text { wholesale market }\end{array}$ & $\begin{array}{c}\text { ASLP mangoes } \\
\text { through } \\
\text { wholesale market }\end{array}$ & $\begin{array}{c}\text { ASLP mangoes } \\
\text { through exclusive } \\
\text { outlet }\end{array}$ \\
\hline Pre-Harvest & Ploughing & 0.625 & 0.625 & 0.625 & 0.625 \\
Costs & Fungicides & 1.25 & 1.25 & 1.25 & 1.25 \\
& Pesticides & 0.875 & 0.875 & 0.875 & 0.875 \\
& Labor & 0.875 & 0.875 & 0.875 & 0.875 \\
& Practices/Pruning & 0.375 & 0.375 & 0.375 & 0.375 \\
& Clearance of Malformation & 0.375 & 0.375 & 0.375 & 0.375 \\
\hline
\end{tabular}

Authors' calculations

Appendix 8. Post-harvest costs at farm level (Rs/Kg).

\begin{tabular}{llcccc}
\hline Description & $\begin{array}{c}\text { Super mangoes } \\
\text { through } \\
\text { wholesale } \\
\text { market }\end{array}$ & $\begin{array}{c}\text { VIP mangoes } \\
\text { through } \\
\text { wholesale } \\
\text { market }\end{array}$ & $\begin{array}{c}\text { ASLP mangoes } \\
\text { through } \\
\text { wholesale } \\
\text { market }\end{array}$ & $\begin{array}{c}\text { ASLP mangoes } \\
\text { through } \\
\text { exclusive outlet }\end{array}$ \\
\hline Farm Level & Harvesting/Picking & 1.25 & 1.25 & 1.25 & 1.25 \\
Operations & $\begin{array}{l}\text { Collection of Fallen Mangoes } \\
\text { Carrying of Mangoes from Farm to Pack }\end{array}$ & - & - & - & - \\
& House & - & 0.125 & 0.125 & 0.125 \\
& $\begin{array}{l}\text { Grading/Packing Cost } \\
\text { Packaging Material Cost (Wooden Box) }\end{array}$ & - & - & - & - \\
Pack House & De-Sapping Cost & - & 4.4 & - & - \\
Operations & Washing to Drying Cost & - & -.25 & 0.25 & 0.25 \\
& $\begin{array}{l}\text { Ripening Cost } \\
\text { Cost of Grading, Labeling and Packing }\end{array}$ & - & - & 6 & 6 \\
& Packing Material Cost & - & 5 & 7 & 7 \\
\hline
\end{tabular}

Authors' calculations 
Appendix 9. Logistics costs paid by the growers (Rs/Kg).

\begin{tabular}{|c|c|c|c|c|}
\hline Description & $\begin{array}{c}\text { Super mangoes } \\
\text { through wholesale } \\
\text { market }\end{array}$ & $\begin{array}{c}\text { VIP mangoes } \\
\text { through wholesale } \\
\text { market }\end{array}$ & $\begin{array}{c}\text { ASLP mangoes } \\
\text { through wholesale } \\
\text { market }\end{array}$ & $\begin{array}{c}\text { ASLP mangoes } \\
\text { through exclusive } \\
\text { outlet }\end{array}$ \\
\hline Loading Cost & 0.5 & 0.5 & 0.5 & 0.5 \\
\hline $\begin{array}{l}\text { Transportation Cost from Farm } \\
\text { to Market }\end{array}$ & 2 & 2 & 1 & 1 \\
\hline Unloading Cost (III) & 0.5 & 0.5 & 0.5 & 0.5 \\
\hline Wholesale Market Fee & 3.22 & 4.55 & 3 & 5 \\
\hline (Commission Fee) & $\begin{array}{l}\text { (For Un-Ripened } \\
\text { Mangoes) }\end{array}$ & $\begin{array}{l}\text { (For Un-Ripened } \\
\text { Mangoes) }\end{array}$ & $\begin{array}{c}\text { (For Ripened } \\
\text { Mangoes in C.B. } \\
\text { Box) }\end{array}$ & $\begin{array}{c}\text { Costs of Operations } \\
\text { and Handling at } \\
\text { Exclusive Retail } \\
\text { Outlet }\end{array}$ \\
\hline Working Capital & 3 & 3 & 3 & 3 \\
\hline
\end{tabular}

Authors' calculations

Appendix 10. Costs incurred by the wholesalers and retailers.

\begin{tabular}{llcccc}
\hline Description & \multicolumn{1}{c}{$\begin{array}{c}\text { Super mangoes } \\
\text { through } \\
\text { wholesale } \\
\text { market }\end{array}$} & $\begin{array}{c}\text { VIP mangoes } \\
\text { through } \\
\text { wholesale } \\
\text { market }\end{array}$ & $\begin{array}{c}\text { ASLP mangoes } \\
\text { through } \\
\text { wholesale } \\
\text { market }\end{array}$ & $\begin{array}{c}\text { ASLP mangoes } \\
\text { through } \\
\text { exclusive outlet }\end{array}$ \\
\hline Wholesaler Costs** & $\begin{array}{l}\text { Costs of Operations and Handling } \\
\text { (Auction) }\end{array}$ & 3 & 3 & 3 & - \\
Retailer's Costs & $\begin{array}{l}\text { Loading, Transportation and Un- } \\
\text { Loading Costs from Wholesale } \\
\text { Market to Retail Outlet }\end{array}$ & 1.66 & 1.66 & 3.33 & - \\
& $\begin{array}{l}\text { Resorting and Grading Cost } \\
\text { Costs of Operations and Handling }\end{array}$ & 2 & & & - \\
Retailers Total Costs*** & 5 & 2 & - & - \\
\hline
\end{tabular}

Authors' calculations

benefits to cost ratios of additional costs and benefits can also be termed as return on additional investment. From the results in the Table 6 , it is quite clear premium quality mangoes incurred highest benefits for the mango growers when marketed directly to high end retail stores. Benefit to cost ratio of producing premium quality mangoes and selling directly to high end retail stores compared to Super Mangoes is 1.96 which indicates that each rupee invested to produce will result into a benefit of about 1.96 rupees showing about 96 per cent profit. The same ration compared to VIP mangoes is 2 reflecting 100 per cent profit and the same ratio compared to premium quality mango sold through commission agent in the whole sale market is 6.7 indicating that each extra rupee invested to sell through high end retail market will born 6.7 rupees. This is one of the important findings that best place for selling premium quality mangoes is high end retail outlets. The possible reasons include the willingness to pay a good price for good quality and preference of customers about quality. The customers in the high end retail outlets are quality conscious and are willing to pay additional price for additional quality. Secondly, commission agents don't have self-interest to sell as their margin was fixed. Growers have benefits to sell premium quality in the wholesale markets through commission agent but only compared with Super mangoes as VIP mangoes have more benefit than premium quality mangoes when sold in the wholesale markets. Bakhsh et al. (2006) and Hanif (2003) found similar results in a mango study conducted in Pakistan. This is reflected by the results of $\mathrm{BCR}$ which is 1.38 in the former case reflecting return of 1.38 rupee of for each extra rupees invested for premium quality mangoes while in the latter case BCR is 0.89 showing less return to premium quality compared with VIP mangoes. This also suggest that VIP mangoes have higher return in the wholesale markets and grower of VIP mangoes can get more benefit from selling in the wholesale markets through commission agents. Jaggaiah (2015) and Bakhsh et al. (2006) supported the BCR result in similar kind of study in India and Pakistan respectively.

Conclusion: Under the pressure of globalization, agricultural marketing system in developing country are in the process of transformation from subsistence level to value chain thinking. The development project such as ASLP mango value chain project encourages growers and entrepreneurs to become more competitive. Building premium quality value chain can generate bigger pie of revenue to share along the chain members, particular for the growers, than the traditional 
subsistence farming. However, finding potential buyers is the key to success for the growers and a continuous support from the relevant Government sector is highly desirable. Government is often the principal actor on agribusiness reforms via its regulatory powers and $\mathrm{R} \& \mathrm{D}$ institutions. There is need to encourage business support services both at the institutional level as well as the commercial level. Publicprivate partnership in processing technologies particularly in the mango production areas can act as catalyst in the transformation of mango industry from traditional to market oriented mango production.

Acknowledgment: This study is conducted under an International project, "Mango Value Chain Improvement" that involves two universities; University of Queensland, Australia and University of Agriculture, Faisalabad, Pakistan. The project is funded by Australian Centre for International Agricultural Research (ACIAR) in the Pakistan's mango Industry. We also acknowledged International Centre for Development and Decent work (ICDD) University Kassel Germany for additional support to refine data.

\section{REFERENCES}

ACIAR. 2006. A Constraint Analysis of Pakistan Mango Supply Chain,. Australian Centre for International Agricultural Research, Government of Australia, Canberra, Australia.

ACIAR. 2007. Domestic market research on superior outlets in Pakistan,. Australian Centre for International Agricultural Research, Government of Australia, Canberra, Australia.

ACIAR. 2014. Prospects and dynamics of Premium Quality mangoes in Pakistan., Australian Centre for International Agricultural Research, Government of Australia, Canberra, Australia.

Bakhsh, K., I. Hassan and M.S. Akhter. 2006. Profitability and cost in growing mango orchards. J. Agri. Soc. Sci. 2:46-50

Batt, P. 2005. Fulfilling customer needs in agribusiness supply chain, pp.83-89. In: P. Batt (ed.), First International Symposium on Improving the Performance of Supply Chains in Transitional Economies, 19-23 July 2005; Chiang Mai, Thailand.

FAO. 2014. FAO Statistical Year Book; Food and agricultural commodities production data. Available online with updates at http://www.fao.org

FAO. 2015. FAO Statistical Year Book; Food and agricultural commodities production data. Available online with updates at http://www.fao.org

Ghafoor, A. 2010. Determinants of mango export from Pakistan. Ph.D Diss., Dept. Marketing and Agribusiness, University of Agriculture Faisalabad, Pakistan.

Government of Pakistan. 2014. Economic survey of Pakistan 2013-14. Ministry of Finance, Government of Pakistan, Islamabad, Pakistan.

Hanif, T. 2003. Economics of growing mango in Khanewal District. MS Diss., Department of Agricultural Economics, university of Agriculture, Faisalabad, Pakistan.

Jaggaiah, T. 2015. Returns of mango orchard and economic feasibility test of mango orchard in Chittoor District of Andhra Perdesh. Ind. J. Appl. Res. 5:598-600

Mankiw, N.G. 2014. Principles of Microeconomics, $7^{\text {th }}$ Ed. Cengage Learning Book Co., Stamford.

McConnell. C.R. and S.L. Brue. 2005. Economics. McGraw Hill Book Co., New York.

Mehdi, M. 2012. Evaluating the Effectiveness of a whole of chain approach in rural industry development in developing countries: a case of Pakistan mango industry. Ph.D. Diss., Gatton Campus, University of Queensland, Australia.

Mehdi, M., A. Adeel, Z. Ahmad and A.F. Hussain. 2014. Effectiveness of a "whole of chain" approach in rural industry development in developing countries: a Case of Pakistan mango industry. UMK Procedia 1:57-62.

PARC. 2009. Characterization of mango value chain. Pakistan Agricultural Research Council, Government of Pakistan, Islamabad, Pakistan.

PHDEC. 2005. Mango marketing strategy. Available online with updates

at http://phdeb.org/MktStrategies/Mango.pdf

PIAM. 2007. Mango value chain analysis. Punjab Institute of Agricultural Marketing, Government of Punjab, Lahore, Pakistan. 